\title{
Assessment of Respiratory Physiology of C57BL/6 Mice following Bleomycin Administration Using Barometric Plethysmography
}

\author{
Phillipa L. Milton ${ }^{a}$ Hayley Dickinson ${ }^{b}$ Graham Jenkin $^{b}$ Rebecca Lim ${ }^{b}$ \\ ${ }^{\mathrm{a}}$ Monash Immunology and Stem Cell Laboratories, Monash University and ${ }^{\mathrm{b}}$ The Ritchie Centre, Monash Institute of \\ Medical Research, Clayton, Vic., Australia
}

\section{Key Words}

Bleomycin model $\cdot$ C57BL/6 mice $\cdot$ Whole-body barometric plethysmography $\cdot$ Lung function should elicit restoration of respiratory parameters in addition to improving traditional biochemical and histological indices of lung function.

Copyright $\odot 2011$ S. Karger AG, Basel

\begin{abstract}
Background: Assessment of deterioration of lung function in animal models of respiratory disease traditionally relies upon quantitating biochemical markers. Plethysmography is a technique for measuring lung function that includes invasive and non-invasive methodologies. Objectives: This study used whole-body barometric plethysmography to characterize change(s) in respiratory physiology of C57BL/6 mice following bleomycin administration. Methods: Cohorts of animals were culled at 3, 7, 14 and 28 days to semiquantitatively score the lung for fibrosis, and quantitate levels of hydroxyproline in the lung. We have described in detail the response of $\mathrm{C57BL} / 6$ mice to bleomycin. Results: Bleomycin-treated mice had reduced minute volume $(p<$ 0.05) and an increased total breathing cycle time $(p<$ $0.0001)$, which consisted of a shortened inspiration time $(p<0.01)$ and an extended expiration time $(p<0.0001)$. Conclusions: We have demonstrated that plethysmography can be a primary indicator of the development of respiratory disease in the mouse and would thus be suitable in assessing potential therapies since any truly effective treatment
\end{abstract}

\section{Introduction}

Quantitative assessment of pulmonary function in animal models of respiratory disease is of scientific importance and clinical relevance. Plethysmography is also used clinically for investigating respiratory physiology of unrestrained human subjects performing their daily activities, and can be modified to take into account position changes [1]. Invasive plethysmography has been used in both ventilated and spontaneously breathing, anaesthetized animals via orotracheal or percutaneous tracheal intubation [2]. Measurements taken from anaesthetized, paralyzed and tracheotomized mice are precise and specific, but are obtained whilst the animal is in an unnatural state [3]. By contrast, unrestrained whole-body plethysmography is a non-invasive procedure whereby respiratory function is precisely measured in conscious, uninstrumented subjects [4]. This non-invasive method of plethysmography is a valuable technique for assessing respiratory physiology as respiratory function of individ-

\section{KARGER}

Fax +41613061234 E-Mail karger@karger.ch www.karger.com

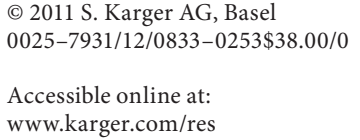


ual animals can be assessed on multiple occasions in longitudinal studies, free of anaesthetic and invasive manipulations $[4,5]$.

The ability of the chemotherapeutic agent bleomycin to induce pulmonary fibrosis has been utilized by researchers in experimental animal models of the human disease pulmonary fibrosis. The bleomycin model is easy to establish, robust, reproducible and versatile [6] and was originally developed in dogs [7], then adapted to mice [8, 9], hamsters [10], rats [11, 12] and rabbits $[13,14]$. To induce pulmonary fibrosis, bleomycin may be administered by various routes, including intratracheal [15], intranasal [16], intraperitoneal [17] and osmotic mini-pump [18] administration. The type, severity and pattern of parenchymal lesions arising following bleomycin administration are route and dose dependent [6]. The potential to induce a variety of lesions offers the advantage of studying pulmonary fibrosis with heterogeneous topography of the lung, a feature similar to some forms of idiopathic interstitial pneumonitis [6].

Investigators often overlook evaluating pulmonary physiological function in animal models of respiratory diseases that aim to assess potential therapies and treatment regimens as biochemical analyses of lung tissue are primarily used as indicators of disease suppression and/ or regression. We aim to use whole-body barometric plethysmography to describe changes in respiratory physiology during the course of disease development and progression in C57BL/6 mice following bleomycin-induced pulmonary fibrosis. This study may provide an accessible and useful analytical technique for evaluating respiratory physiology, which would have a wide application in animal models of respiratory diseases and would be especially useful for investigating the efficacy of new drugs, treatment strategies and regimens, which are currently being developed as therapies for human pulmonary fibrosis.

\section{Materials and Methods}

\section{Animals}

All experimental procedures were approved by the School of Biomedical Sciences Animal Ethics Committee at Monash University and conducted in accordance with the Australian Code of Practice for the Care and Use of Animals for Scientific Purposes (2006).

The adult female C57BL/6 mice used in this study were obtained from the Animal Resources Centre, Perth, W.A., Australia. Upon commencement of the study, animals were $19.0 \pm 0.08 \mathrm{~g}$ in weight and aged 8-12 weeks. C57BL/6 mice were housed in a specific pathogen-free temperature- and humidity-controlled room $\left(21.0 \pm 1.0^{\circ} \mathrm{C}\right.$ and $50.0 \pm 10.0 \%$, respectively) with a 12 -hour light-dark cycle. Mice had access to water and food ad libitum.

Plethysmography for Assessment of Lung Function

The plethysmograph used to measure pulmonary function in vivo was modified from that previously described for assessing pulmonary function in guinea pigs [19]. The plethysmograph (fig. 1) consisted of a single cylindrical Perspex chamber $(150 \times$ $50 \mathrm{~mm}$ ) with a temperature and relative humidity probe (model HM34; serial No. 413576; Vaisala, Finland) inserted at one end. A volumetric pressure transducer (model PT5A; serial No. L302P4; Grass Instrument Co., Quincy, Mass., USA) and a 1-ml calibration syringe were inserted at the other end of the chamber. The pressure transducer measured the change in pressure caused by the tidal movement of gas within the chamber. This signal was then amplified (Octal Bridge Amp model ML228; Powerlab 8/30 model ML870; AD Instruments) and recorded with a data recording program (Chart 5 for Windows, version 5.1) using a standard desktop PC. Animal core temperatures were measured with a rectal thermometer (Livingstone) prior to recording. The pulmonary function of each mouse was recorded for a maximum of $45 \mathrm{~s}$ and, if during this time the animal was not stationary and calm, the chamber ends were removed for re-equilibration of the chamber with the external environment and, after several minutes, recordings were taken again and the original recording discarded.

\section{Plethysmography Analyses}

Waveform analysis (Chart 5 for Windows, version 5.1) was used to analyse the respiratory trace obtained from each animal. This consisted of the change in pressure caused by the tidal movement of gas within the chamber $\left(\mathrm{P}_{\mathrm{T}}\right)$ and a pressure deflection that related to a volume of air injected for calibration $\left(\mathrm{V}_{\mathrm{k}}\right)$. The respiratory parameters of breathing frequency (f, breaths/min), total breathing cycle time $\left(\mathrm{T}_{\text {tot }}, \mathrm{s}\right)$, inspiration time $\left(\mathrm{T}_{\mathrm{i}}, \mathrm{s}\right)$ and expiration time $\left(T_{e}, s\right)$ were derived directly from the respiratory trace and were taken from regions of the trace void of sniffing or movement waveforms. To calculate tidal volume $\left(\mathrm{V}_{\mathrm{T}}, \mathrm{ml}\right)$, the $\mathrm{P}_{\mathrm{T}}$ value obtained from the respiratory trace was inputted into the equation of Drorbaugh and Fenn [20] as below.

$$
\begin{aligned}
& \mathrm{V}_{\mathrm{T}}=\left(\mathrm{P}_{\mathrm{T}} / \mathrm{P}_{\mathrm{k}}\right) \times\left(\mathrm{V}_{\mathrm{k}}\right) \times\left(\left(\mathrm{T}_{\text {core }}\left(\mathrm{P}_{\mathrm{B}}-\mathrm{P}_{\mathrm{C}}\right)\right) /\left(\mathrm{T}_{\text {core }}\left(\mathrm{P}_{\mathrm{B}}-\mathrm{P}_{\mathrm{C}}\right)-\mathrm{T}_{\mathrm{C}}\right.\right. \\
& \left.\left.\left(\mathrm{P}_{\mathrm{B}}-\mathrm{P}_{\text {core }}\right)\right)\right),
\end{aligned}
$$

where $\mathrm{V}_{\mathrm{T}}=$ tidal volume; $\mathrm{P}_{\mathrm{k}}=$ pressure deflection due to each injection of $1 \mathrm{ml}$; $\mathrm{T}_{\text {core }}=$ core temperature of each animal; $\mathrm{P}_{\mathrm{C}}=$ water vapour pressure at chamber temperature (water vapour pressure at chamber temperature $\times$ relative humidity in chamber); $\mathrm{T}_{\mathrm{C}}=$ temperature in animal chamber; $\mathrm{P}_{\text {core }}=$ pressure at body temperature (water vapour pressure at body temperature $\times 1.0$ ); $\mathrm{P}_{\mathrm{T}}=$ pressure deflection due to each tidal volume; $\mathrm{V}_{\mathrm{k}}=$ volume injected for calibration; $\mathrm{P}_{\mathrm{B}}=$ barometric pressure.

Once tidal volume had been determined, minute volume $\left(\mathrm{V}_{\mathrm{E}}\right.$, $\left.\mathrm{ml} / \mathrm{min} ; \mathrm{V}_{\mathrm{T}} \times \mathrm{f}\right)$, inspiratory duty cycle $\left(\mathrm{T}_{\mathrm{i}} / \mathrm{T}_{\text {tot }}, \%\right)$, inspiratory flow rate $\left(\mathrm{V}_{\mathrm{T}} / \mathrm{T}_{\mathrm{i}}, \mathrm{ml} / \mathrm{s}\right)$ and the ratio of inspiration time to expiration time $\left(\mathrm{T}_{\mathrm{i}} / \mathrm{T}_{\mathrm{e}}\right.$ ratio) were also calculated.

\section{Experimental Design}

Body weight and basal lung function of the C57BL/6 mice were recorded prior to administering bleomycin or vehicle (saline). These parameters were recorded again at 3, 7, 14, 21 and 28 days following administrations. After the recordings on days 3, 7, 14 


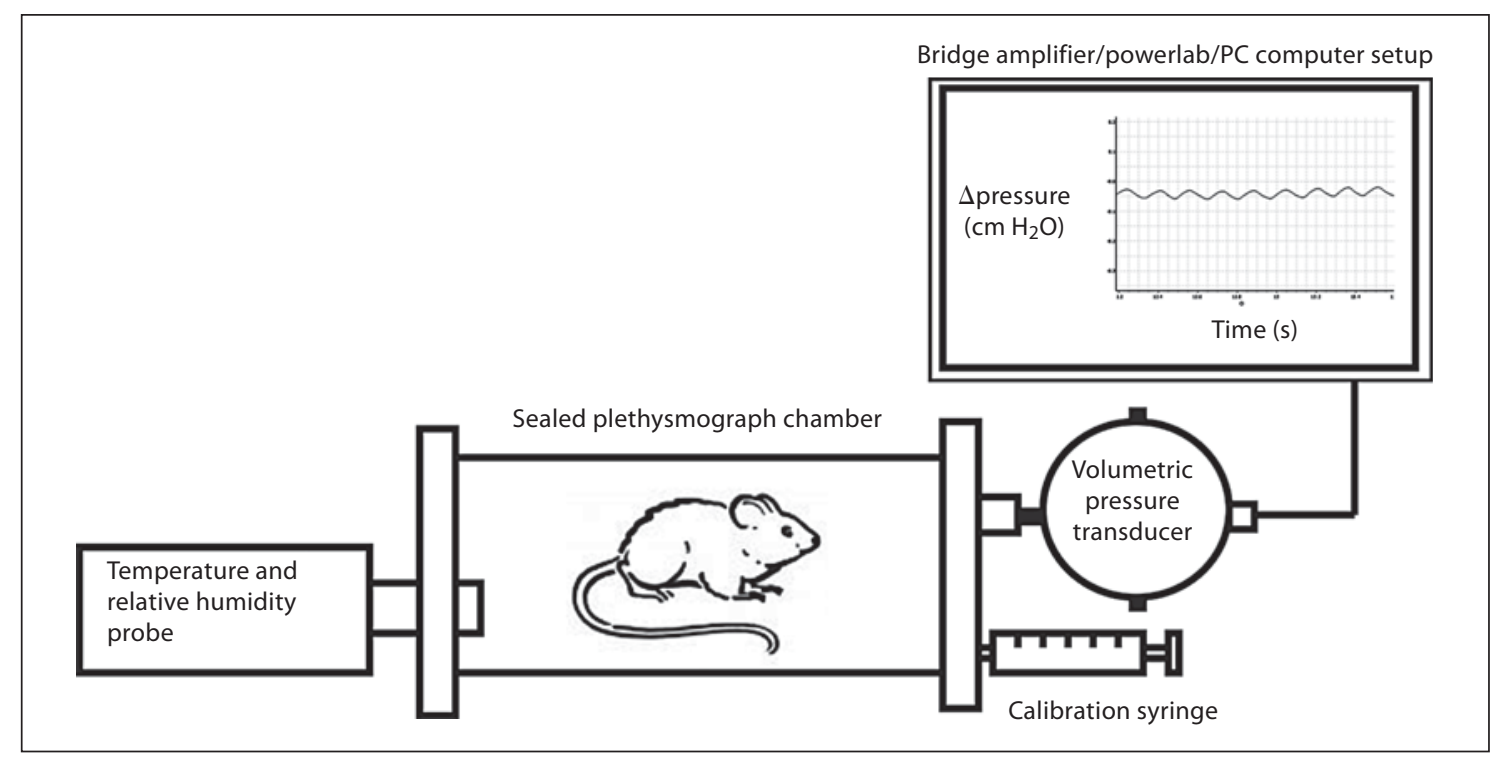

Fig. 1. A schematic diagram illustrating the design of the barometric plethysmograph used to measure pulmonary function. The plethysmograph consisted of a single cylindrical Perspex chamber with a temperature and relative humidity probe inserted at one end. A volumetric pressure transducer and a 1-ml calibration syringe were inserted at the other end of the chamber.

and 28 , a cohort of animals ( $\mathrm{n}=15$ at days $3,7,14 ; \mathrm{n}=5$ at day 28 ) were culled from the untreated control and bleomycin treatment groups for tissue collection and analyses as described below.

Bleomycin Induction of Pulmonary Fibrosis

Under light isoflurane (Attane ${ }^{\mathrm{TM}}$, Minrad, N.S.W., Australia) anesthesia, a bolus intranasal administration of bleomycin (Sigma, USA) was administered to C57BL/6 mice to induce pulmonary fibrosis. A range of doses ( $\mathrm{mg} /$ mouse) were trialled $(0.15,0.2$, $0.25,0.275 .0 .3,0.35$ and 0.4$)$, with $0.25 \mathrm{mg} /$ mouse $(\mathrm{n}=50)$ being the selected dose as pulmonary fibrosis was induced consistently in all animals with no mortality (data not shown). Control mice received saline alone by the same procedure $(n=50)$.

\section{Tissue Collection}

Animals were culled by an intraperitoneal injection of $150 \mathrm{mg} /$ $\mathrm{kg}$ Lethobarb (Virbac, Australia). The right lung was ligated at the right mainstem bronchus, excised and weighed to determine wet lung weight. The right lung was then processed for the hydroxyproline assay as described below. Upon excising the right lung, the trachea was then exposed, cannulated and the left lung was instilled with $10 \%$ phosphate-buffered formalin at $25 \mathrm{~cm} \mathrm{H}_{2} \mathrm{O}$ pressure. The left lung was then excised and immersed in the same fixative for $48 \mathrm{~h}$ and processed for paraffin embedding. Serial sections, at $5 \mu \mathrm{m}$ in thickness, were then taken and stained with Masson's trichrome or haematoxylin and eosin.

\section{Ashcroft Score of Fibrosis and Semi-Quantitative}

Morphological Index

A numerical fibrotic score (Ashcroft scale [21]) was obtained as follows; the severity of the fibrotic changes was determined as the mean score and standard error of the mean (SEM) from more than 25 microscopic fields at $200 \times$ magnification for each lung section, and each field was assessed individually for severity and allotted a score from 0 (normal) to 8 (total fibrosis). All lung sections were evaluated in a blinded fashion by two independent observers.

Morphological changes in lung sections were graded semiquantitatively as previously published [22, 23]. Three histological sections per lung were graded using the following criteria: $0=$ normal lung; $1=$ minimal areas of inflammation, epithelial hyperplasia and fibrosis, usually limited to subpleural foci in just 1 or 2 sections; 2 = more frequent lesions; 3 = all 3 sections exhibit lung lesions which are not limited to subpleural foci; $4=$ extensive lesions in at least 2 of 3 sections, and $5=$ the majority of each of 3 lung sections affected by inflammation and fibrosis.

\section{Hydroxyproline Assay for Collagen}

The excised right lung was lyophilized to dry weight to determine the hydroxyproline content as described previously [24]. The hydroxyproline concentrations were expressed as a proportion of animal body weight (micrograms hydroxyproline per lung lobe).

\section{Statistical Analyses}

Results are expressed as means \pm SEM. Lung function parameters, body weight and body temperature data were evaluated for statistical significance using the repeated-measures general linear model analysis in SPSS (version 13.0). Parameters that were statistically significant were then analysed by multiple analysis of variance (ANOVA) with a Bonferroni post hoc analysis of time, with treatment as the fixed factor. A two-way ANOVA was used to determine differences in wet lung weight data and histological scores. Statistical significance was tested to the $5 \%$ level $(\mathrm{p}<0.05)$. 

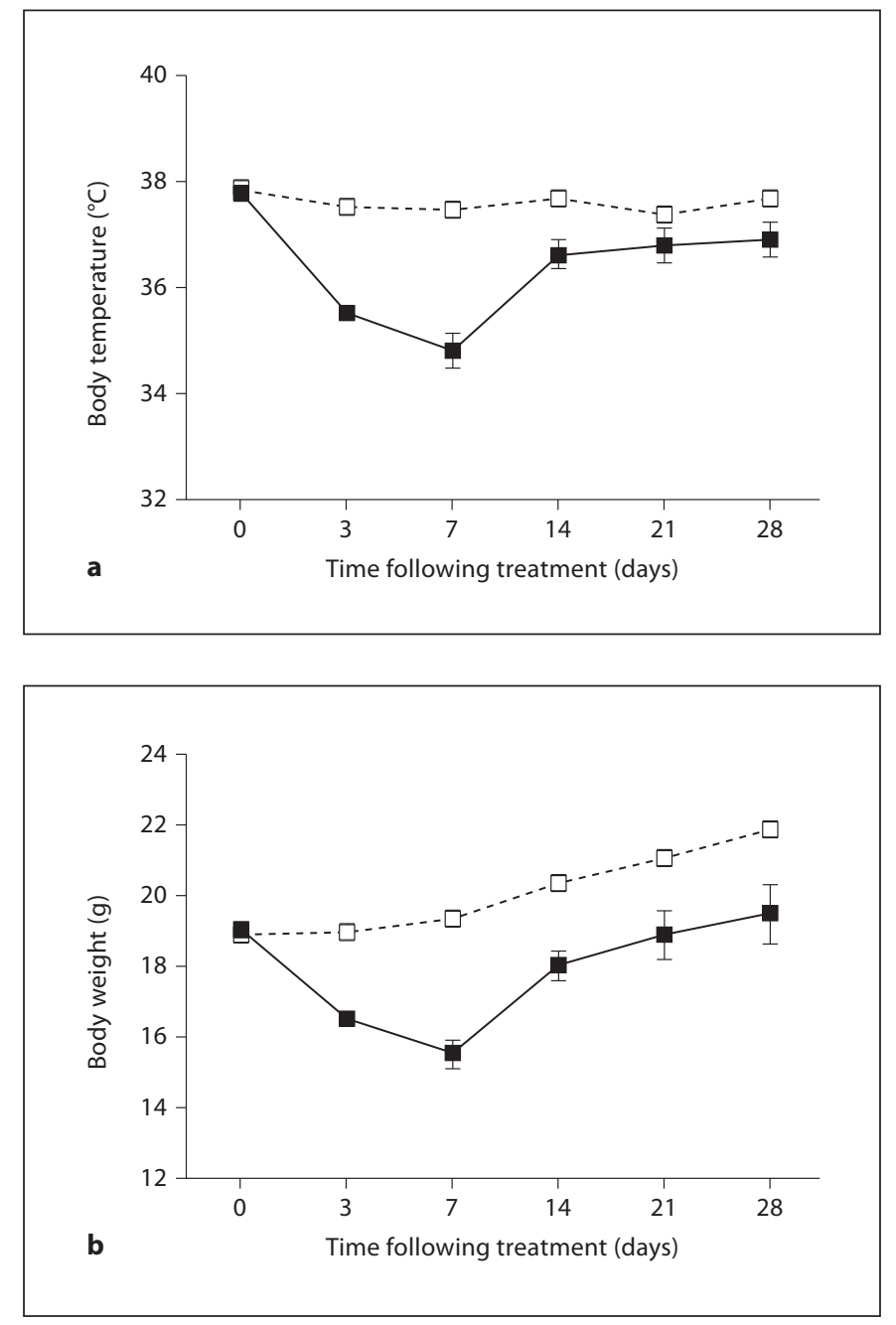

Fig. 2. Effect of bleomycin on body temperature and weight of C57BL/6 mice. a Body temperature; repeated-measures ANOVA $\mathrm{p}=0.06$. b Body weight; repeated-measures ANOVA $\mathrm{p}=0.09$. Note that when days 21 and 28 were excluded from the statistical analyses, an overall significant difference was observed between vehicle controls (dashed line) and bleomycin-treated animals (solid line) C57BL/6 mice for body temperature $(\mathrm{p}<0.0001)$ and weight $(\mathrm{p}<0.0001)$.

\section{Results}

Effect of Bleomycin on Body Temperature and Weight

Bleomycin treatment had a similar effect on both core body temperature and weight (fig. 2). The overall differences observed between vehicle control and bleomycin-treated C57BL/6 mice over the 28 -day study period were not statistically significant for either body temperature (fig. $2 \mathrm{a}, \mathrm{p}=0.06$ ) or weight (fig. $2 \mathrm{~b}, \mathrm{p}=$ $0.09)$. However, when days 21 and 28 were excluded from the statistical analyses, there was an overall significant difference observed between vehicle control and bleomycin-treated C57BL/6 mice for body temperature $(\mathrm{p}<$ $0.0001)$ and weight $(\mathrm{p}<0.0001)$. Within 7 days of bleomycin treatment, C57BL/6 mice had experienced a loss in body temperature and weight from an initial $37.7 \pm$ $0.06^{\circ} \mathrm{C}$ and $19.07 \pm 0.8 \mathrm{~g}$ to $34.8 \pm 0.30^{\circ} \mathrm{C}$ and $15.5 \pm$ $0.4 \mathrm{~g}$, respectively, compared to vehicle control mice which maintained a consistent body temperature (37.6 $\left.\pm 0.04^{\circ} \mathrm{C}\right)$ and weight $(19.35 \pm 0.08 \mathrm{~g})$ for the duration of the 28 -day study period. From days 7 to 28 , bleomycin-treated $\mathrm{C} 57 \mathrm{BL} / 6$ mice regained body temperature and weight to within basal levels, reaching values of $36.94 \pm 0.32^{\circ} \mathrm{C}$ and $19.48 \pm 0.8 \mathrm{~g}$, respectively, by day 28 (fig. 2).

\section{Plethysmography for Assessment of Lung Function}

Effect of Bleomycin on Tidal Volume, Respiratory

Rate, and Minute Ventilation

The overall differences observed in tidal volume between untreated control and bleomycin-treated mice over the study period were not statistically significant. Three days after bleomycin administration, tidal volume of bleomycin-treated mice was reduced but returned to within basal levels by day 7 (fig. 3a). When tidal volume was calculated relative to body weight, it was maximal at day $7(5.03 \pm 0.19 \mathrm{ml} / \mathrm{kg})$ but returned to within basal levels by day 14 (fig. $3 \mathrm{~b}$ ).

There was an overall significant difference observed between untreated control and bleomycin-treated C57BL/ 6 mice for breathing frequency $(\mathrm{p}<0.0001)$, with days 3, 7 and 14 significantly different to days 0,21 and 28 ( $p<0.0001$; fig. 3c). Respiratory rate of bleomycintreated C57BL/6 mice decreased by $40.8 \%$ from an initial $348.21 \pm 3.8$ breaths $/$ min to $206.34 \pm 5.9$ breaths $/ \mathrm{min}$ by day 3 . This rate was maintained until day 7 , at which point, breathing frequency began to increase to within basal levels by day 21 (335.11 \pm 36.5 breaths/min; fig. 3c). When expressed relative to body weight, significant differences were only seen on days 3 and 7 ( $p<0.0001$; fig. 3d).

Minute volume was also significantly different between vehicle control and bleomycin-treated C57BL/6 mice $(p<0.05)$, and showed a similar trend from that of breathing frequency, whereby minute volume on days 3 and 7 was significantly different to that on days $0,14,21$ and 28 ( $\mathrm{p}<0.0001$; fig. 3e). Bleomycin-treated C57BL/6 mice had experienced a $49.2 \%$ reduction in minute volume by day 3 following treatment, which gradually increased to within basal levels by day 21 (fig. 3e). When 

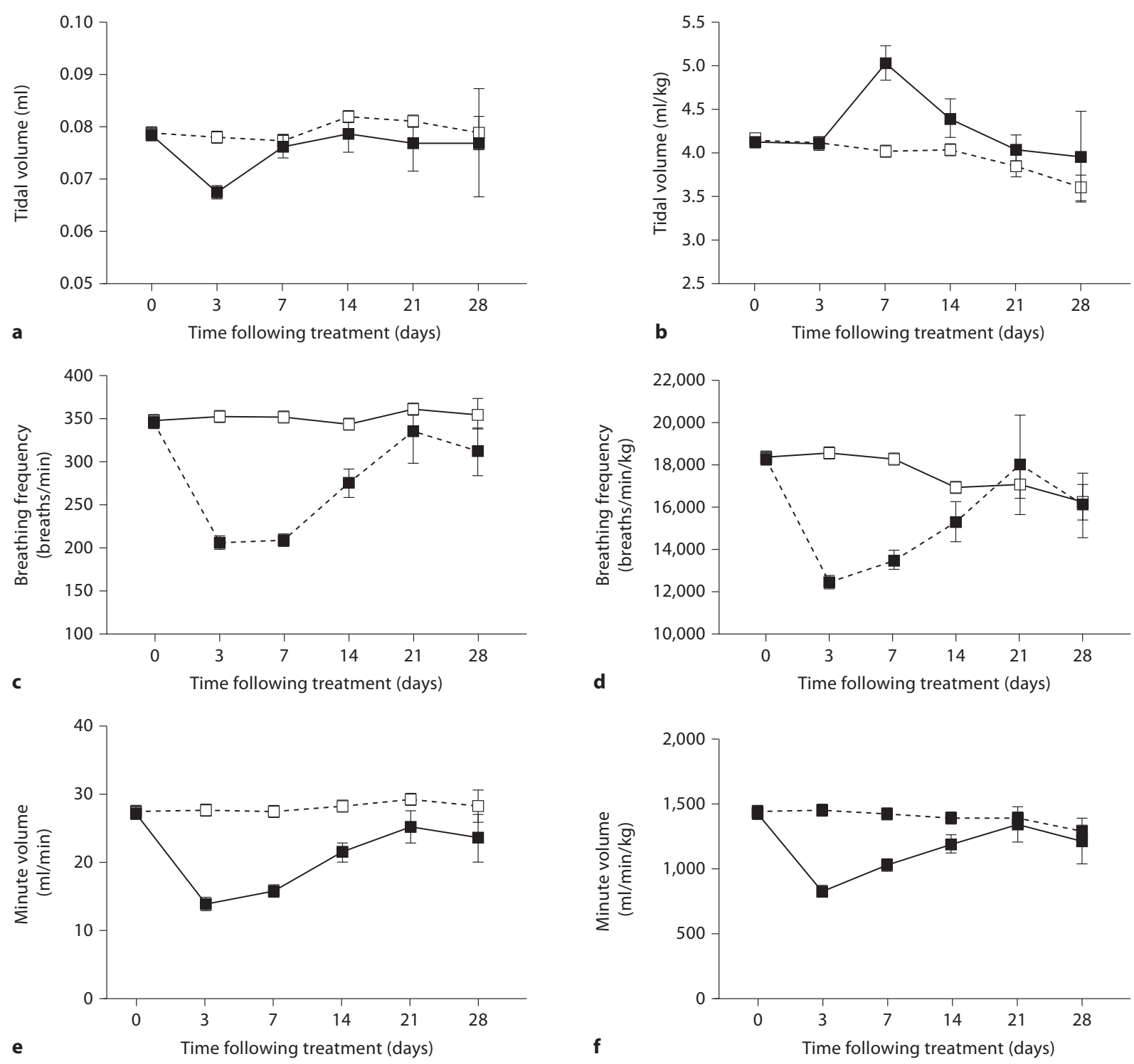

Fig. 3. Effect of bleomycin on pulmonary tidal volume (ml; ml/ $\mathrm{kg}$ ), breathing frequency and minute volume ( $\mathrm{ml} / \mathrm{min} ; \mathrm{ml} / \mathrm{min} /$ $\mathrm{kg}$ ) of C57BL/6 mice. Vehicle controls represented by dashed line; bleomycin-treated animals represented by solid line. a Tidal volume; repeated-measures ANOVA $p>0.05$. b Tidal volume relative to body weight; repeated-measures ANOVA $p>0.05$. c Breathing frequency; repeated-measures ANOVA $p<0.0001$; Bonferroni post hoc: days 3,7 and 14 were significantly different to days 0,21 and 28 ( $\mathrm{p}<0.0001)$. d Breathing frequency relative to body weight; repeated-measures ANOVA $\mathrm{p}<0.0001$; Bonferroni post hoc: days 14,21 and 28 were significantly different to day 0 and day 7 ( $p<$ 0.01). e Minute volume; repeated-measures ANOVA $\mathrm{p}<0.05$; Bonferroni post hoc: days 3 and 7 were significantly different to days $0,14,21$ and $28(\mathrm{p}<0.0001)$. $\mathrm{f}$ Minute volume relative to body weight; repeated-measures ANOVA $p>0.05$. 


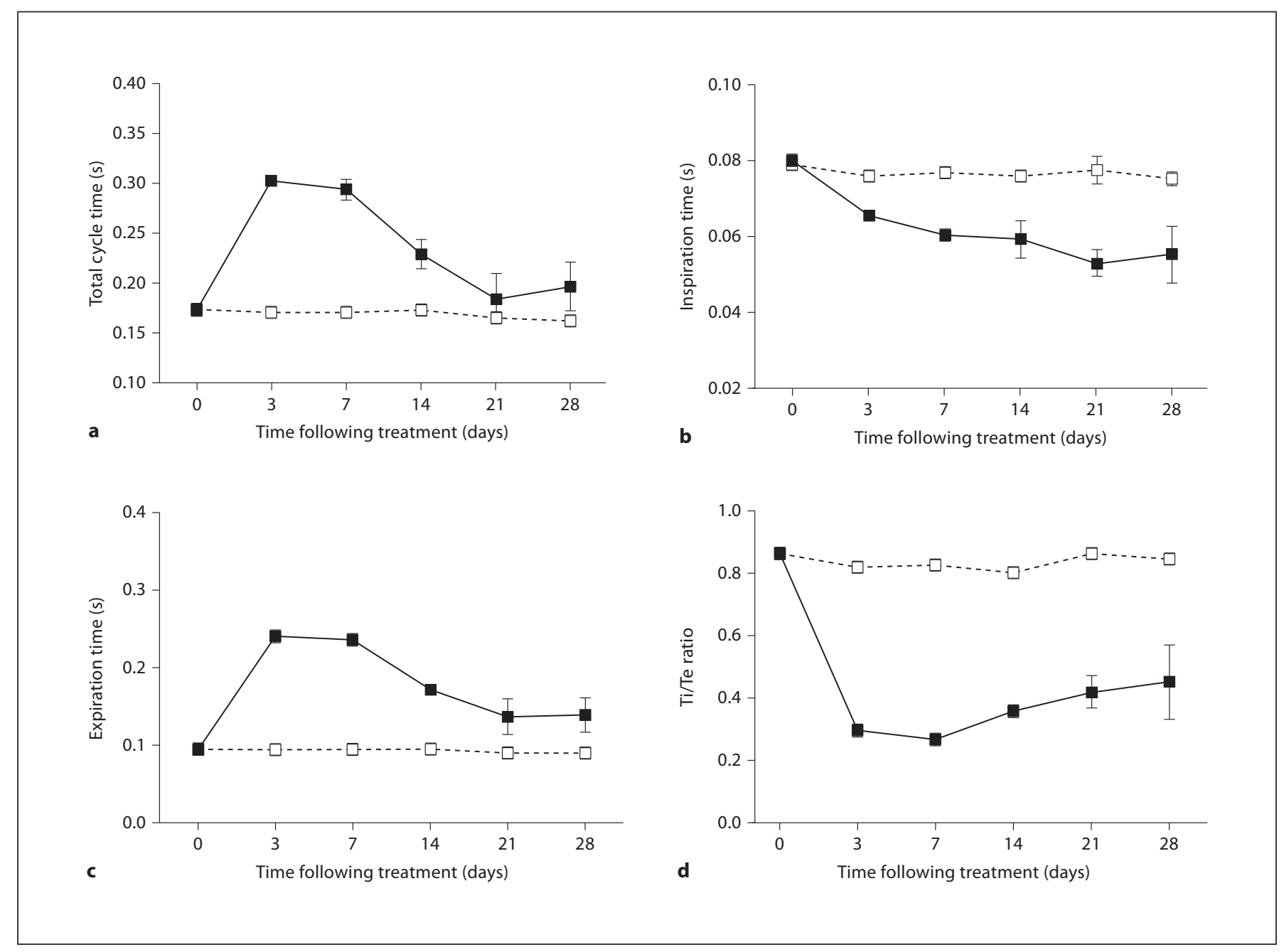

Fig. 4. Effect of bleomycin on pulmonary total breathing cycle time, inspiration time, expiration time and the ratio of inspiration time to expiration time for $\mathrm{C} 57 \mathrm{BL} / 6$ mice. Vehicle controls represented by dashed line; bleomycin-treated animals represented by solid line. a Total breathing cycle time; repeated-measures ANOVA $p<0.0001$; Bonferroni post hoc: days 3 and 7 were significantly different to days $0,14,21$ and $28(\mathrm{p}<0.0001)$. b Inspiration time; repeated-measures ANOVA $\mathrm{p}<0.01$; Bonferroni post hoc:

minute volume was calculated relative to body weight, the overall differences observed between vehicle control and bleomycin-treated mice were not significant (fig. 3f).

Following bleomycin treatment, tidal volume and minute volume were significantly positively correlated $(\mathrm{r}=0.48 ; \mathrm{p}<0.0001)$. Minute volume and breathing frequency were also significantly positively correlated $(\mathrm{r}=$ $0.84 ; \mathrm{p}<0.0001)$ while tidal volume and breathing frequency were negatively correlated $(r=-0.05 ; p>0.05)$.

all time points of analyses were significantly different to basal readings ( $p<0.0001)$. c Expiration time; repeated-measures ANOVA $\mathrm{p}<0.0001$; Bonferroni post hoc: days 3 and 7 were significantly different to days $0,14,21$ and 28 ( $\mathrm{p}<0.0001)$. d Ratio of inspiration time to expiration time; repeated-measures ANOVA $\mathrm{p}<0.0001$; Bonferroni post hoc: all time points of analyses were significantly different to basal readings $(\mathrm{p}<0.0001)$.

Effect of Bleomycin on Total Cycle Time, Inspiration Time, Expiration Time and Inspiratory/Expiratory

Ratio

The overall differences observed for total breathing cycle time between vehicle control and bleomycin-treated C57BL/6 mice were statistically significant $(\mathrm{p}<0.0001)$, with days 3 and 7 significantly different to days $0,14,21$ and 28 ( $\mathrm{p}<0.0001$; fig. 4a). By day 3 following bleomycin administration, treated C57BL/6 mice had a significantly longer total breathing cycle time $(0.30 \pm 0.01 \mathrm{~s} ; \mathrm{p}<$ 
0.0001; fig. 4a) compared to the cycle time at the time of treatment $(0.17 \pm 0.002 \mathrm{~s})$. Breathing cycle time of bleomycin-treated C57BL/6 mice remained extended until day 7 , at which point it began to shorten and was not significantly different to basal levels by day $21(0.18 \pm$ $0.02 \mathrm{~s})$.

Total breathing cycle time was further analysed with respect to the duration of inspiration and expiration. For inspiration time, there was an overall significant difference observed between vehicle control and bleomycintreated C57BL/6 mice $(\mathrm{p}<0.01)$, with all time points of analyses significantly different to basal readings ( $\mathrm{p}<$ 0.0001; fig. 4b). Similarly, there was an overall statistically significant difference observed between vehicle control and bleomycin-treated C57BL/6 mice for expiration time ( $\mathrm{p}<0.0001)$, with days 3 and 7 significantly different to days $0,14,21$ and 28 ( $p<0.0001$; fig. 4 c). Like total breathing cycle time, by day 3 following bleomycin administration, inspiration and expiration times were both significantly different to basal levels ( $\mathrm{p}<0.0001$ ). Inspiration time was significantly shorter and expiration time significantly longer, with durations of $0.066 \pm$ $0.001 \mathrm{~s}$ and $0.24 \pm 0.01 \mathrm{~s}$ at day 3 compared to basal levels of $0.081 \pm 0.001 \mathrm{~s}$ and $0.092 \pm 0.001 \mathrm{~s}$, respectively (fig. $4 b, c$ ). For the remainder of the study period, from day 3 to day 28 , inspiration time continued to become increasingly shorter for bleomycin-treated C57BL/6 mice compared to vehicle controls. Expiration time remained extended between 3 and 7 days following treatment at which point, like total breathing cycle time, it began to shorten towards basal readings (fig. $4 \mathrm{~b}, \mathrm{c}$ ).

Over the study period, the ratio of inspiration time to expiration time was significantly different between vehicle control and bleomycin-treated mice $(p<0.0001)$, with all time points of analyses significantly different to basal readings ( $p<0.0001$; fig. $4 \mathrm{~d}$ ). Vehicle control animals had a symmetrical breathing cycle, $\mathrm{T}_{\mathrm{i}} \mathrm{T}_{\mathrm{e}}$ ratio, with inspiration and expiration times of essentially equal duration, indicated by a ratio close to $1.0(0.86 \pm 0.01)$. Prior to treatment, mice receiving bleomycin also had a symmetrical breathing trace $(0.88 \pm 0.01)$; however, by day 3 , the $T_{i} / T_{e}$ ratio was significantly smaller $(0.29 \pm$ $0.01 ; \mathrm{p}<0.0001)$. The $\mathrm{T}_{\mathrm{i}} / \mathrm{T}_{\mathrm{e}}$ ratio for bleomycin-treated C57BL/6 mice from day 3 and for the remainder of the study period remained below 0.5 , indicating an asymmetric breathing cycle (fig. $4 \mathrm{~d}$ ).

Following bleomycin treatment, inspiration and expiration times were significantly positively correlated with total breathing cycle time, with $\mathrm{r}$ values of 0.42 ( $\mathrm{p}<$ $0.0001)$ and $0.97(\mathrm{p}<0.0001)$, respectively.

Bleomycin and Respiratory Physiology of C57BL/6 Mice
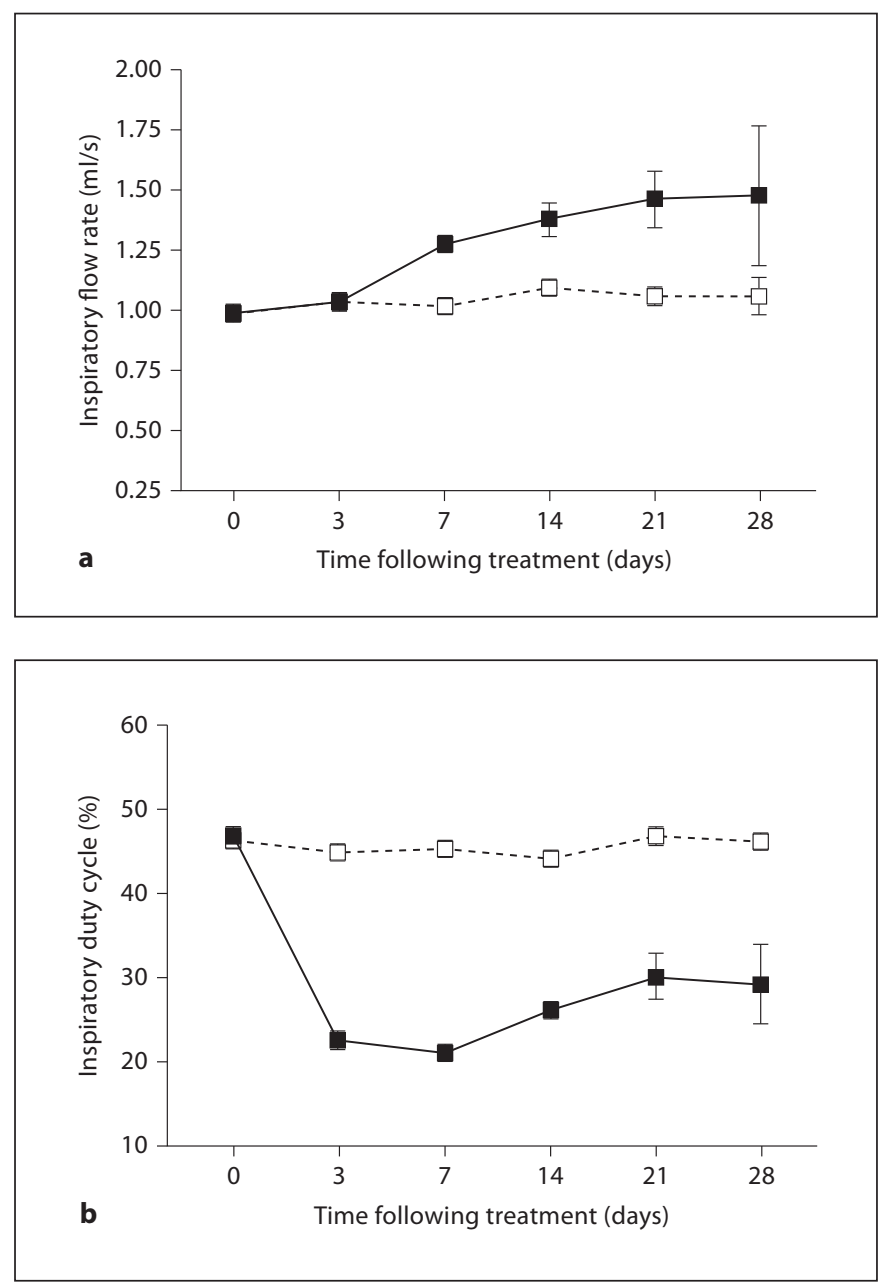

Fig. 5. The effect of bleomycin on pulmonary inspiratory flow rate and inspiratory duty cycle of C57BL/6 mice. Vehicle controls represented by dashed line; bleomycin-treated animals represented by solid line. a Inspiratory flow rate; repeated-measures ANOVA $\mathrm{p}<0.05$; Bonferroni post hoc: days 7, 14, 21 and 28 were significantly different to basal readings and day 3 ( $p<0.0001)$. b Inspiratory duty cycle; repeated-measures ANOVA $p<0.0001$; Bonferroni post hoc: all time points of analyses were significantly different to basal readings $(\mathrm{p}<0.0001)$.

\section{Effect of Bleomycin on Inspiratory Flow Rate and}

Inspiratory Duty Cycle

The overall differences observed between vehicle control and bleomycin-treated mice for inspiratory flow rate were significant $(\mathrm{p}<0.05)$, with days $7,14,21$ and 28 , significantly different to basal readings and those recorded at day 3 following treatment ( $<<0.0001$; fig. $5 \mathrm{a}$ ). Mice treated with bleomycin experienced a gradual increase in inspiratory flow rate from day $3(1.04 \pm 0.02 \mathrm{ml} / \mathrm{s})$, and for the remainder of the study period, until a maximum

Respiration 2012;83:253-266 

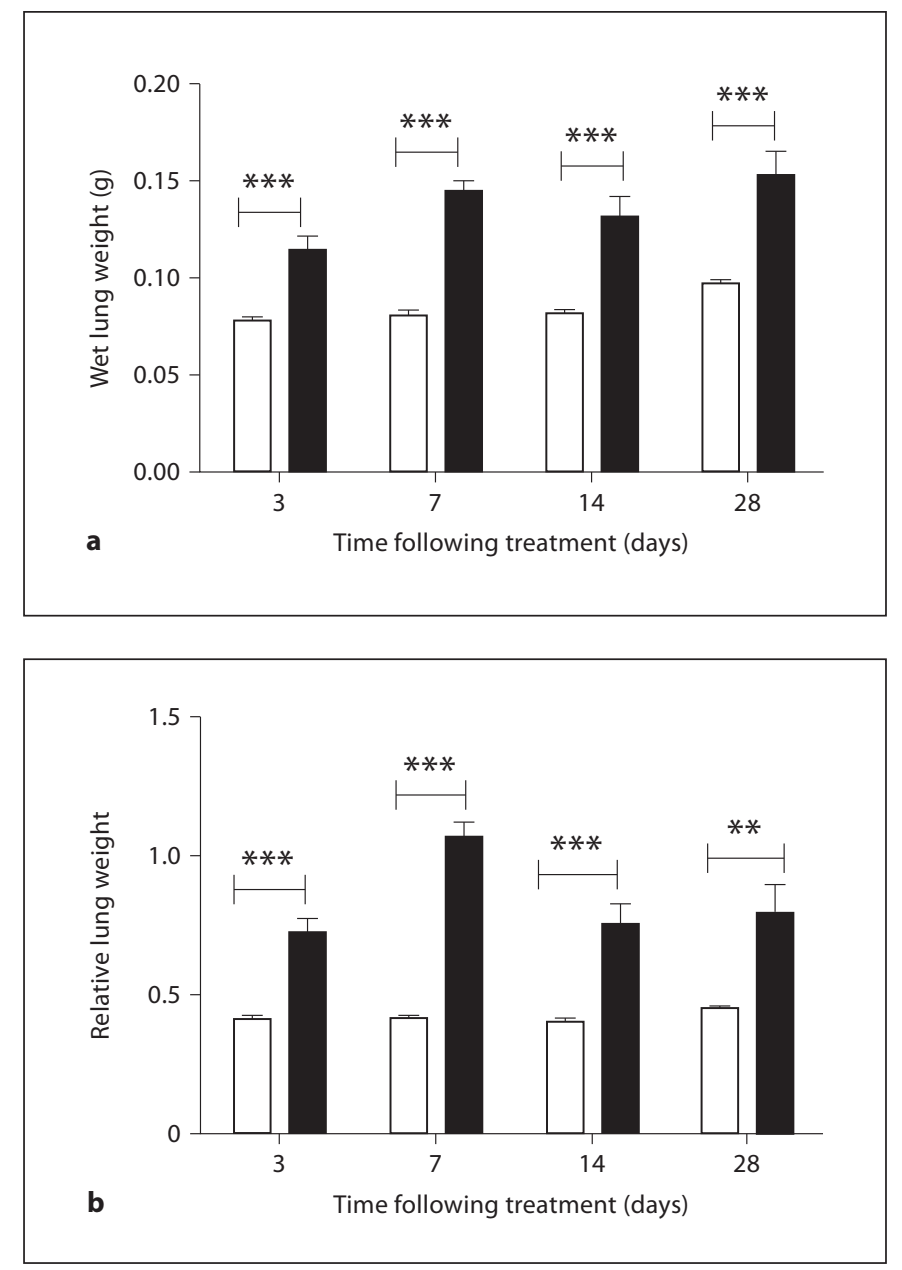

Fig. 6. Lung weights of C57BL/6 mice following bleomycin treatment. Vehicle controls represented by open bar; bleomycin-treated animals represented by solid bar. a Wet lung weights; two-way ANOVA $\mathrm{p}<0.0001$. b Wet lung weights relative to body weight; two-way ANOVA $\mathrm{p}<0.0001$, with significant differences between groups indicated by ${ }^{* *}(\mathrm{p}<0.01)$ and ${ }^{* *}(\mathrm{p}<0.001)$.

of $1.48 \pm 0.29 \mathrm{ml} / \mathrm{s}$ was reached by day 28 (fig. $5 \mathrm{a}$ ). Mice in the vehicle control group had a stable inspiratory flow rate of $0.99 \pm 0.01 \mathrm{ml} / \mathrm{s}$ for the duration of the study period.

Similarly, there was an overall significant difference observed between vehicle control and bleomycin-treated mice for inspiratory duty cycle $(\mathrm{p}<0.0001)$, with all time points of analyses significantly different to basal readings ( $p<0.0001$; fig. 5b). Bleomycin-treated C57BL/6 mice had experienced a $51.8 \%$ reduction in inspiratory duty cycle by day 3 following treatment. Between days 7 and 21, inspiratory duty cycle had partially recovered (30.11 \pm
$2.73 \%)$ but not to within basal levels (46.98 $\pm 0.27 \%$; fig. 5b). This is compared to vehicle control mice that had a stable inspiratory duty cycle of $46.34 \pm 0.32 \%$ for the duration of the study period.

Following bleomycin treatment, inspiratory flow rate and inspiratory duty cycle were significantly negatively correlated with total breathing cycle time, with $\mathrm{r}=-0.30$ $(\mathrm{p}<0.01)$ and $\mathrm{r}=-0.70(\mathrm{p}<0.0001)$, respectively.

\section{Lung Weights}

An overall significant difference was observed in wet lung weights between vehicle control and bleomycintreated mice ( $p<0.0001$; fig. $6 \mathrm{a}$ ). At each time point of analysis, mice in the bleomycin-treated group had significantly heavier lungs than mice in the vehicle control group, with wet lung weights of $0.115 \pm 0.007 \mathrm{~g}(\mathrm{p}<$ $0.001), 0.145 \pm 0.006 \mathrm{~g}(\mathrm{p}<0.001), 0.133 \pm 0.011 \mathrm{~g}(\mathrm{p}<$ $0.001)$ and $0.153 \pm 0.013 \mathrm{~g}(\mathrm{p}<0.001)$, at days $3,7,14$ and 28 , respectively. Mice in the vehicle control group had a wet lung wet of approximately $0.084 \pm 0.004 \mathrm{~g}$ for the duration of the study period (fig. 6a). The wet lung weight relative to body weight values had a similar trend to the wet lung weights per se, with an overall significant difference observed between vehicle control and bleomycintreated mice $(\mathrm{p}<0.0001)$, and also between vehicle control and bleomycin-treated mice at each time point studied ( $\mathrm{p}<0.01$; fig. $6 \mathrm{~b})$.

\section{Ashcroft Score of Fibrosis and Semi-Quantitative Morphological Index}

Lungs of vehicle control mice had normal alveolar architecture with no evidence of extracellular matrix accumulation or inflammatory cell infiltrate. Bleomycintreated mice had patchy lesions in the pulmonary architecture, which were characterized by areas of dense inflammatory cell infiltrate that obliterated the alveoli and which were interspersed with areas of less severe lesions, where alveolar walls were thickened and fibrous masses and bands had accumulated (fig. 7). There was an overall significant difference observed between untreated control and bleomycin-treated mice for the severity of parenchymal lesions by Ashcroft scoring $(\mathrm{p}<0.0001)$ and the morphological index $(\mathrm{p}<0.0001)$. At each time point of analysis, mice in the bleomycin-treated group had significantly more severe and widespread distribution of lesions than those in the vehicle control group $(p<0.001)$, with Ashcroft scores of $4.48 \pm 0.34,5.62 \pm 0.82$ and 5.22 \pm 0.20 at days 3,14 and 28 , respectively (fig. $7,8 \mathrm{a}$ ). The most severe parenchymal lesions were of a subpleural, perivascular, peribronchial and bronchiolocentric distri- 

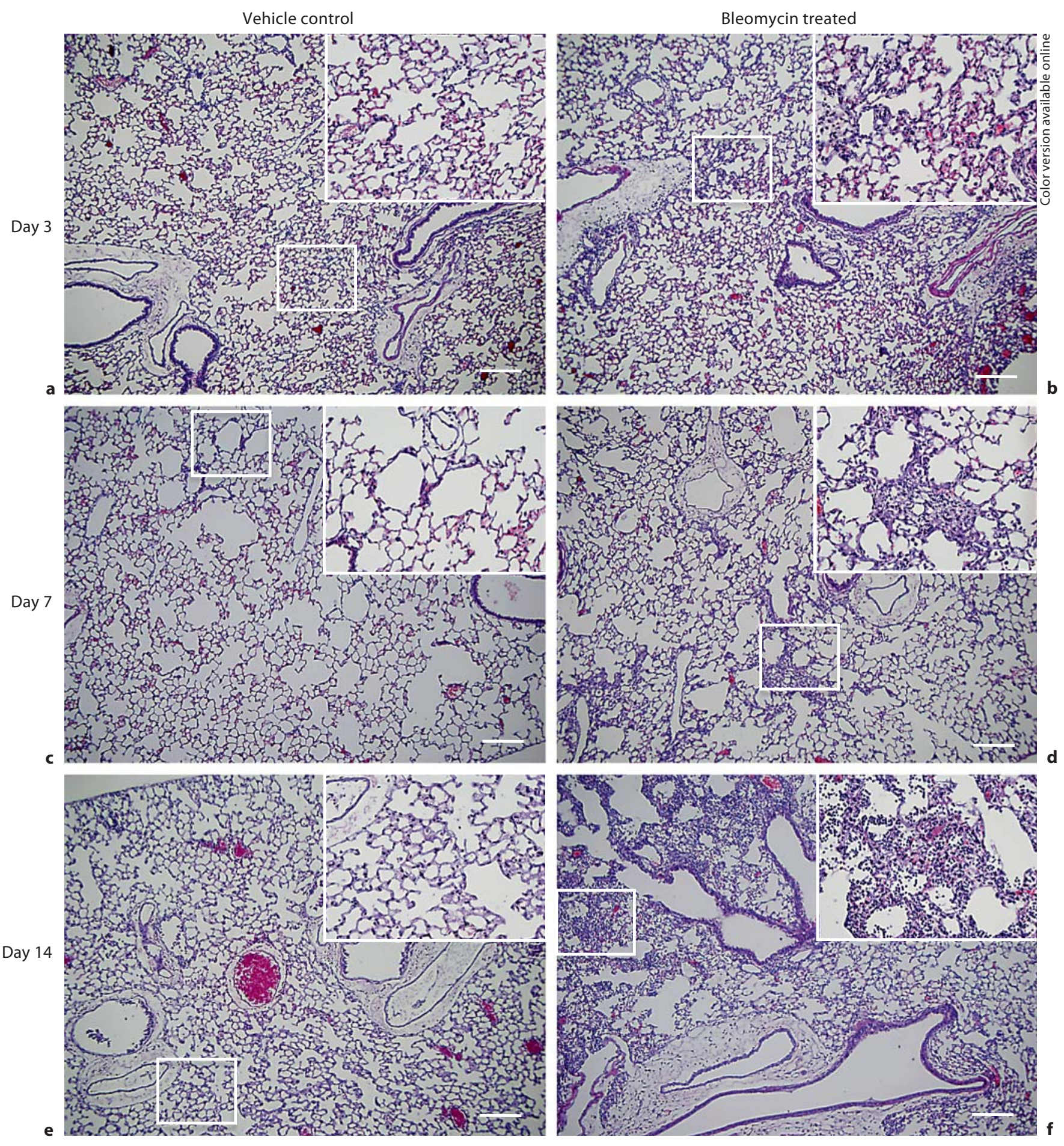

Fig. 7. Representative images of lungs from bleomycin-treated C57BL/6 mice, stained with hematoxylin and eosin. C57BL/6 mice in the vehicle control group had normal parenchymal architecture with no evidence of inflammatory cell infiltrate or thickened alveolar walls at days 3 (a), 7 (c) or 14 (e). This was compared to that observed in C57BL/6 mice in the bleomycin-treated group, which had thickened alveolar walls and evidence of the initial onset of inflammatory cell infiltration into the lung $(\mathbf{b})$. By day 7

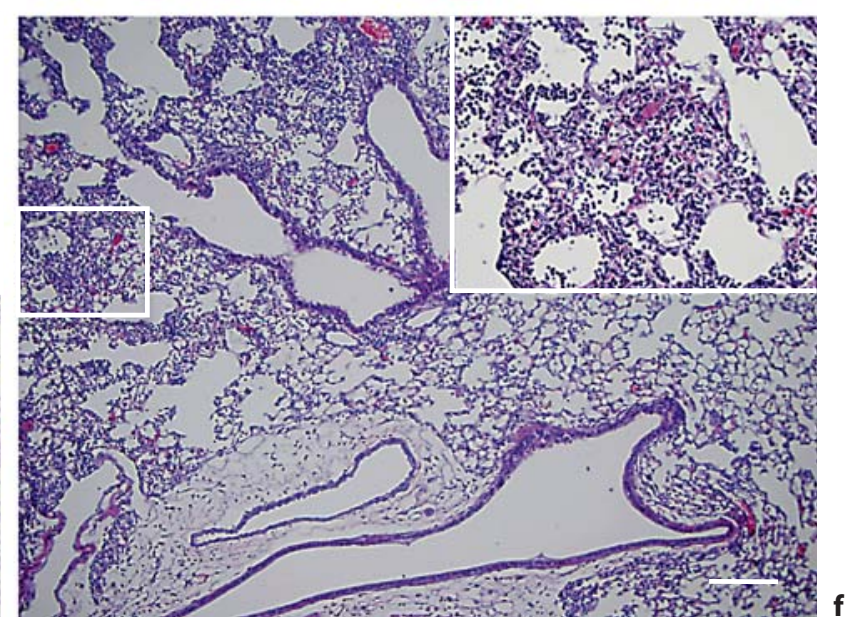

following bleomycin administrations, the infiltration of inflammatory cells was widespread throughout the lung parenchyma, and alveoli in regions of the lung were obliterated due to cellular infiltration (d). The extent of these lesions was more severe in the lungs of C57BL/6 mice in the bleomycin-treated group by day 14 (f). Note that day-28 images were unavailable. Images were taken at $100 \times$ magnification. Insets were taken at $400 \times$ magnification. Scale bars $=50 \mu \mathrm{m}$. 

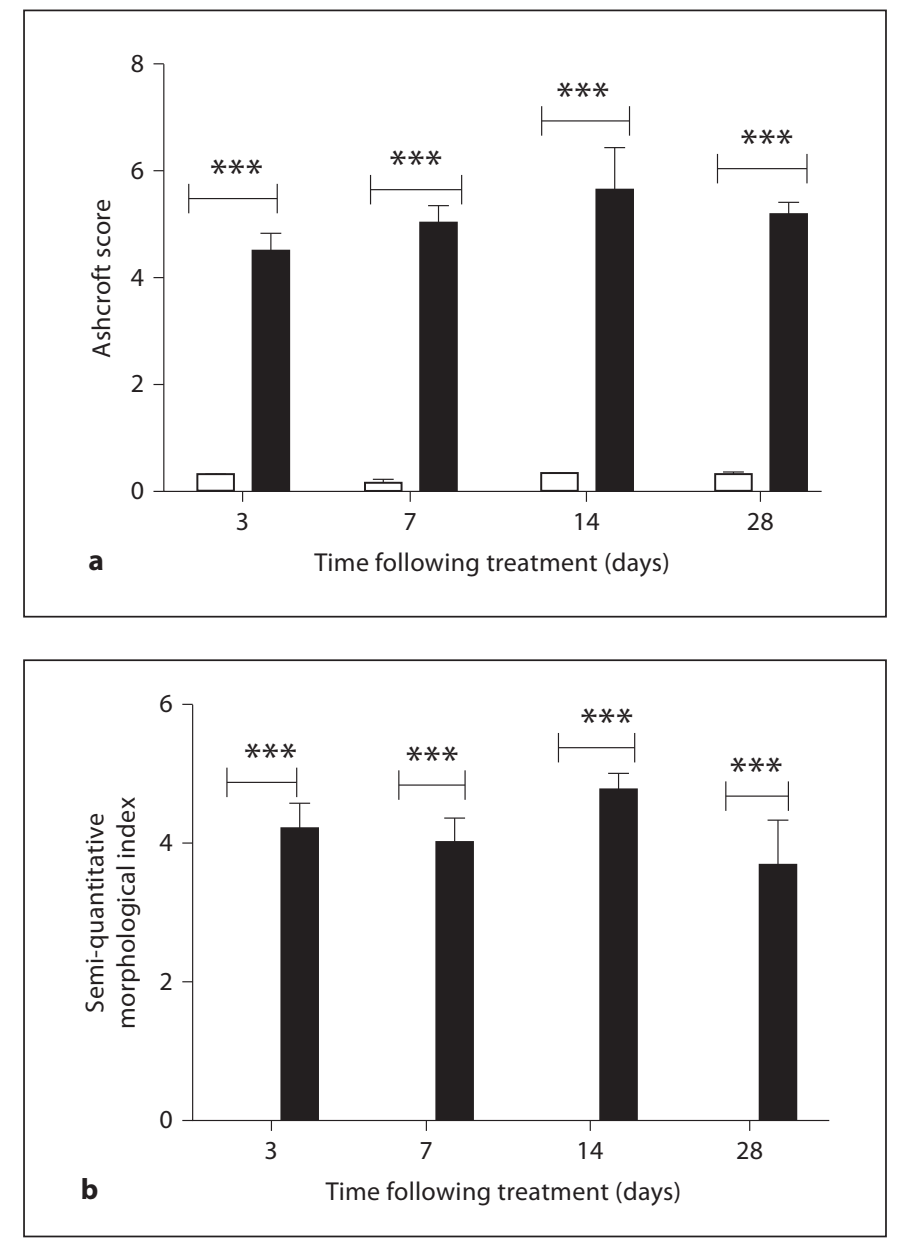

Fig. 8. Effect of bleomycin on the Ashcroft score of fibrosis and the semi-quantitative morphological index in the lungs of C57BL/6 mice. Vehicle controls represented by open bar; bleomycin-treated animals represented by solid bar. a Ashcroft score of fibrosis; two-way ANOVA $\mathrm{p}<0.0001$. b The semi-quantitative morphological index; two-way ANOVA $p<0.0001$, with significant differences between groups indicated by ${ }^{* *}(p<0.001)$. Note that saline control mice had no detectable lesions in the pulmonary architecture and the semi-quantitative morphological index was 0 at all time points for the saline control group.

bution (fig. 8b). At day 14, lungs of bleomycin-treated mice had the most severe and widespread distribution of lesions.

\section{Hydroxyproline Assay for Collagen}

There was an overall significant difference observed between vehicle control and bleomycin-treated mice for hydroxyproline content in the lung $(\mathrm{p}<0.0001$; fig. 9). At day 7 , hydroxyproline concentration in the lung of bleomycintreated mice was significantly greater than that in vehicle

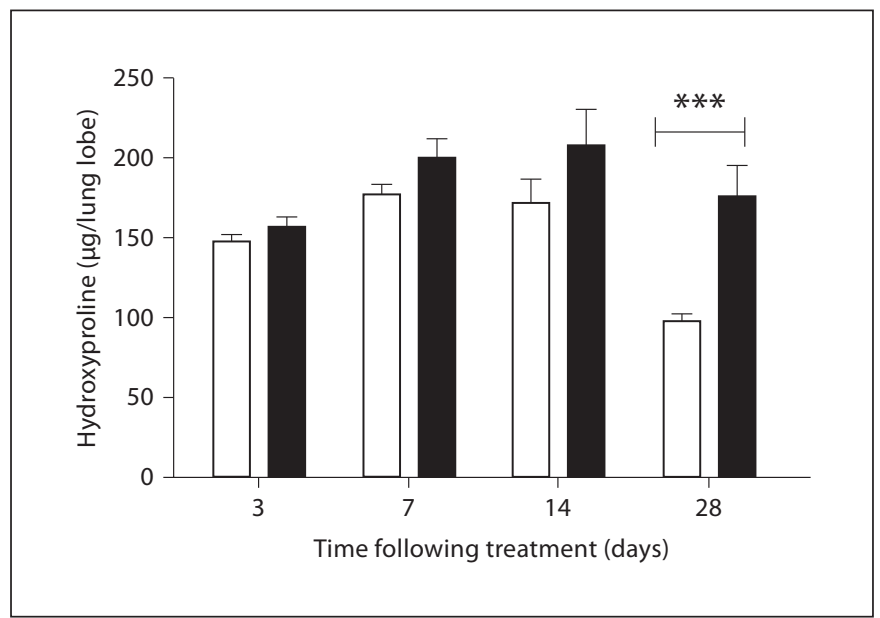

Fig. 9. The hydroxyproline content in lungs of C57BL/6 mice following bleomycin induction of pulmonary fibrosis. Vehicle controls represented by open bar; bleomycin-treated animals represented by solid bar. Two-way ANOVA $\mathrm{p}<0.0001$, with significant differences between groups indicated by ${ }^{* *}(\mathrm{p}<0.01)$ and *** $(\mathrm{p}<0.001)$.

control mice $(14.77 \pm 1.21$ and $9.44 \pm 0.29 \mu \mathrm{g} / \mathrm{g}$, respectively). Similarly, bleomycin-treated C57BL/6 mice had a significantly greater hydroxyproline concentration in the lung than vehicle control mice at day 28 following administration $(9.11 \pm 1.19$ and $4.42 \pm 0.27 \mu \mathrm{g} / \mathrm{g}$, respectively). Interestingly, we noted that hydroxyproline content was lower 28 days following vehicle instillation compared to 3 , 7 and 14 days following instillation. This may indicate some extent of injury brought on by saline instillation.

\section{Discussion}

Using a non-invasive method of unrestrained wholebody barometric plethysmography, we described in detail the changes in respiratory physiology and breathing cycle parameters of C57BL/6 mice following bleomycin induction of pulmonary fibrosis. Recently, Vanoirbeek et al. [25] published their findings on invasive and non-invasive methods of measuring pulmonary functions in obstructive and restrictive diseases, where lung function was analysed at a single time point following various asthmatic, emphysematic and bleomycin challenges. Unique to our study, we show the changes to respiratory physiology in bleomycin injured mice over time by employing exhaustive techniques in unrestrained wholebody plethysmography and histological analyses. 
Following bleomycin administration, the pulmonary function of C57BL/6 mice was adversely affected, whereby significant changes in volumetric and breathing cycle parameters were observed. These changes were a likely consequence of the severe morphological alterations occurring in the lung following bleomycin treatment, which manifested as a heterogeneous distribution of dense inflammatory cell infiltrate and accumulations of fibrous masses and bands in the lung parenchyma, coupled with thickening of the alveolar walls, all of which are observations consistent with previous reports [26-28]. Likewise, as with previous reports, bleomycin-treated C57BL/6 mice developed pulmonary oedema, deduced from the significant increase in wet lung weights following bleomycin treatment, compared to vehicle control mice [29, 30]. Furthermore, albeit not a significant difference, the observed reduction in body weight of bleomycin-treated C57BL/6 mice was likely to be the outcome of the brisk inflammatory response occurring in the lung as previously reported [29, 31-35].

Collectively, the morphological changes occurring in the lungs of bleomycin-treated C57BL/6 mice were likely to have reduced the surface area available for gas exchange, a defining characteristic of the bleomycin model $[8,36]$. As a result, bleomycin-treated C57BL/6 mice experienced a loss in respiratory function, which was characterized by a decrease in tidal volume. In order to minimize the work of breathing, the observed reduction in tidal volume was accompanied by a decrease in breathing frequency, a normal physiological response [37]. C57BL/6 mice had a rapid, shallow breathing pattern, which was likely to have been due to lung vagal afferents, which are known to cause this breathing pattern following bleomycin induction of pulmonary fibrosis in animals $[38,39]$.

In addition to causing a loss in respiratory function, the significant morphological changes occurring in the lung following bleomycin treatment develop in association with extracellular matrix remodelling, which collectively impact on the oscillatory mechanics of the lung [8, $36,40]$. As a consequence of the parenchymal lesions and extracellular matrix remodelling, lungs of bleomycintreated animals in models of pulmonary fibrosis have reduced compliance [41], increased elastic recoil, which is the inverse of compliance [42], and an increase in lung resistance $[40,43]$. Given that the observed morphological changes in lungs of C57BL/6 mice are consistent with previous reports, the properties of altered compliance, elastic recoil and resistance are likely to apply to our model. This, in turn, is likely to have resulted in the significant changes in the physiological cyclic parameters observed.
The total breathing cycle time of bleomycin-treated C57BL/6 mice was significantly increased following bleomycin administration. This change in the length of the breathing cycle was due in part to the development of an asymmetric breathing pattern, characterized by a proportionately longer expiration time than inspiration time. As a consequence of the inferred reduced compliance in the lungs of bleomycin-treated C57BL/6 mice, and as expiration is normally a passive process [37], inspiration was likely to have been more difficult and therefore required greater effort. There was thus a significant increase in inspiratory flow rate, the active component of the breathing cycle, which was accompanied by a significant reduction in inspiratory duty cycle, the timing component of the breathing cycle. Thus, the rate of airflow during inspiration increased with a consequent reduction in the duration and contribution of inspiration to the breathing cycle. Furthermore, the significant increase observed in expiration time following bleomycin treatment may be attributed to the greater tissue resistance in the lungs of bleomycin-treated C57BL/6 mice. These observations were in contrast to those observed in vehicle control C57BL/6 mice, which maintained a symmetric breathing pattern for the duration of the study period, whereby inspiration and expiration were of essentially equal duration, in addition to maintaining a steady inspiratory flow rate and duty cycle.

Measuring pulmonary function in animal models of respiratory disease is of scientific importance and clinical relevance. Several studies have reported the use of plethysmography following bleomycin treatment [40, 43-50]. Of the reported studies, the majority utilized invasive plethysmography on anaesthetized mice supported by mechanical ventilation at a rate of 150 breaths/min, a tidal volume of 7.5-8 $\mathrm{ml} / \mathrm{kg}$ and a positive end-expiratory pressure of approximately $3-4 \mathrm{~cm} \mathrm{H}_{2} \mathrm{O}[40,43,44,50]$. Invasive plethysmography is useful in assessing respiratory mechanics, such as static compliance, lung resistance and elasticity; however, these procedures are tedious, require surgery, and measurements are taken whilst the animal is in a manipulated and unnatural state. Furthermore, the invasive nature of the procedure does not permit longitudinal studies in individual animals. Micro-computed tomography has been utilized several studies to assess lung compliance of bleomycintreated animals; however, this procedure is tedious and expensive [46-48].

Another technology widely available for measuring respiratory parameters is the forced oscillation technique. This allows for the detection of subtle changes in compar- 
ison to whole-body plethysmography; however, the forced oscillation technique requires the termination of animals, unlike whole-body plethysmography, which allows repeat measurements on the same unrestrained unanaesthetized animal. It is also important to note that while whole-body plethysmography appeared to yield expected and significant changes in the bleomycin injury model used in this study, its application across to allergic airway disease models may be limited. It has been previously suggested that whole-body plethysmography is more reliable for detecting changes to breathing patterns than it is for detecting changes to lung mechanics $[54,55]$. While whole-body plethysmography and enhanced pause $\left(\mathrm{P}_{\mathrm{enh}}\right)$ have their merits in helping our understanding of respiratory physiology in disease processes, we caution against their use as standalone methods for lung function analysis.

Reported studies that included whole-body barometric plethysmography following bleomycin treatment, only briefly examined breathing frequency, tidal volume or $\mathrm{P}_{\mathrm{enh}}$, which is a measure of airway function and bronchoconstriction and is calculated from the pressure, measured by the plethysmograph as a function of time $[45,49$, 51]. There is debate regarding the validity of $P_{\text {enh }}$ as an indicator of bronchoconstriction and its representation of airway function [51-53]. Despite the limited assessment of respiratory parameters in the reported studies which utilized plethysmography following bleomycin treatment, whole-body barometric plethysmography can provide a substantial quantity of lung function data that quantify volumetric and cyclic breathing parameters as demonstrated by this study on C57BL/6 mice, especially given that multiple recordings over time can be performed on any individual animal with no residual effects of anaesthesia or surgery.

Analyses of lung function in animal studies of respiratory disease are frequently overlooked as investigators primarily focus on utilizing the outcome of biochemical analyses of lung tissue as indicators of disease suppres- sion and/or regression [30, 33, 56-62]. The results from this study on C57BL/6 mice illustrate that the inclusion of whole-body barometric plethysmography would benefit any study utilizing the bleomycin animal model of pulmonary fibrosis, particularly if potential therapies are being investigated, as this technique is appropriate for the longitudinal assessment of disease progression, regression and restoration of respiratory function. In the assessment of the effectiveness of potential therapeutic agents, respiratory physiology and evaluation of improvement in respiratory parameters are fundamental to the identification of improved lung mechanics.

In summary, this study characterized the kinetics of respiratory physiology and breathing cycle parameters of C57BL/6 mice following bleomycin administration in an animal model of pulmonary fibrosis. Given the considerable impact of pulmonary fibrosis on respiratory function and mechanics, the results of this study have demonstrated that whole-body barometric plethysmography would be a useful addition to animal studies investigating potential therapies, and should form one of the primary indicators of disease progression and regression as any truly effective treatment would elicit restoration of respiratory parameters in addition to improvement of traditional biochemical and histological indices of lung function.

\section{Acknowledgments}

Appreciation is extended to Prof. John Wilson (Department of Allergy, Immunology and Respiratory Medicine, The Alfred Hospital) for providing advice on the manuscript.

This research was partially funded by an NHMRC Project Grant No. 491145 and the Victorian Government's Operational Infrastructure Support Program. P.L.M. was in receipt of an Australian Stem Cell Centre Premier Scholarship during her PhD studies. H.D. is supported by an ARC Australian Post-Doctoral Research Fellowship.
References
-1 Brüllmann G, Fritsch K, Thurnheer R, Bloch KE: Respiratory monitoring by inductive plethysmography in unrestrained subjects using position sensor-adjusted calibration. Respiration 2010;79:112-120.

2 Hoymann HG: Invasive and noninvasive lung function measurements in rodents. J Pharmacol Toxicol Methods 2007;55:16-26.

-3 Bates JH, Irvin CG: Measuring lung function in mice: the phenotyping uncertainty principle. J Appl Physiol 2003;94:1297-1306.
4 Irvin CG, Bates JH: Measuring the lung function in the mouse: the challenge of size. Respir Res 2003;4:4.

5 Flandre TD, Leroy PL, Desmecht DJ: Effect of somatic growth, strain, and sex on double-chamber plethysmographic respiratory function values in healthy mice. J Appl Physiol 2003;94:1129-1136.

-6 Moeller A, Ask K, Warburton D, Gauldie J, Kolb M: The bleomycin animal model: a useful tool to investigate treatment options for idiopathic pulmonary fibrosis? Int J Biochem Cell Biol 2008;40:362-382. 
7 Fleischman RW, Baker JR, Thompson GR, Schaeppi UH, Illievski VR, Cooney DA, Davis RD: Bleomycin-induced interstitial pneumonia in dogs. Thorax 1971;26:675682.

-8 Adamson IY, Bowden DH: The pathogenesis of bleomycin-induced pulmonary fibrosis in mice. Am J Pathol 1974;77:185-197.

>9 Harrison JH, Jr., Lazo JS: Plasma and pulmonary pharmacokinetics of bleomycin in murine strains that are sensitive and resistant to bleomycin-induced pulmonary fibrosis. J Pharmacol Exp Ther 1988;247:1052-1058.

-10 Snider GL, Hayes JA, Korthy AL: Chronic interstitial pulmonary fibrosis produced in hamsters by endotracheal bleomycin: pathology and stereology. Am Rev Respir Dis 1978;117:1099-1108.

11 Thrall RS, McCormick JR, Jack RM, McReynolds RA, Ward PA: Bleomycin-induced pulmonary fibrosis in the rat: inhibition by indomethacin. Am J Pathol 1979;95: 117-130.

-12 Phan SH, Thrall RS, Ward PA: Bleomycininduced pulmonary fibrosis in rats: biochemical demonstration of increased rate of collagen synthesis. Am Rev Respir Dis 1980; 121:501-506.

13 Laurent GJ, McAnulty RJ, Corrin B, Cockerill P: Biochemical and histological changes in pulmonary fibrosis induced in rabbits with intratracheal bleomycin. Eur J Clin Invest $1981 ; 11: 441-448$.

14 Bigby TD, Allen D, Leslie CG, Henson PM, Cherniack RM: Bleomycin-induced lung injury in the rabbit. Analysis and correlation of bronchoalveolar lavage, morphometrics, and fibroblast stimulating activity. Am Rev Respir Dis 1985;132:590-595.

-15 Volmer JB, Thompson LF, Blackburn MR: Ecto-5'-nucleotidase (CD73)-mediated adenosine production is tissue protective in a model of bleomycin-induced lung injury. J Immunol 2006;176:4449-4458.

-16 Manoury B, Nenan S, Leclerc O, Guenon I, Boichot E, Planquois JM, Bertrand CP, Lagente $\mathrm{V}$ : The absence of reactive oxygen species production protects mice against bleomycin-induced pulmonary fibrosis. Respir Res 2005;6:11.

$\checkmark 17$ Lok SS, Haider Y, Howell D, Stewart JP, Hasleton PS, Egan JJ: Murine gammaherpes virus as a cofactor in the development of pulmonary fibrosis in bleomycin resistant mice. Eur Respir J 2002;20:1228-1232.

- 18 Fujimoto H, Gabazza EC, Taguchi O, Nishii Y, Nakahara H, Bruno NE, D’AlessandroGabazza CN, Kasper M, Yano Y, Nagashima M, Morser J, Broze GJ, Suzuki K, Adachi Y: Thrombin-activatable fibrinolysis inhibitor deficiency attenuates bleomycin-induced lung fibrosis. Am J Pathol 2006;168:10861096.

-19 McGregor HP, Westcott K, Walker DW: The effect of prenatal exposure to carbon monoxide on breathing and growth of the newborn guinea pig. Pediatr Res 1998;43:126-131.
20 Drorbaugh JE, Fenn WO: A barometric method for measuring ventilation in newborn infants. Pediatrics 1955;16:81-87.

21 Ashcroft T, Simpson JM, Timbrell V: Simple method of estimating severity of pulmonary fibrosis on a numerical scale. J Clin Pathol 1988;41:467-470.

-22 Berkman N, Kremer S, Or R, Lossos IS, Christensen TG, Goldstein RH, Breuer R: Human recombinant interferon- $\alpha 2 \mathrm{a}$ and interferon- $\alpha \mathrm{a} / \mathrm{d}$ have different effects on bleomycin-induced lung injury. Respiration 2001;68:169-177.

23 Lossos IS, Izbicki G, Or R, Goldstein RH, Breuer R: The effect of suramin on bleomycin-induced lung injury. Life Sci 2000;67: 2873-2881.

24 Bergman I, Loxley R: Lung tissue hydrolysates: Studies of the optimum conditions for the spectrophotometric determination of hydroxyproline. Analyst 1969;94:575-584.

25 Vanoirbeek JA, Rinaldi M, De Vooght V, Haenen S, Bobic S, Gayan-Ramirez G, Hoet PH, Verbeken E, Decramer M, Nemery B, Janssens W: Noninvasive and invasive pulmonary function in mouse models of obstructive and restrictive respiratory diseases. Am J Respir Cell Mol Biol 2010;42:96-104

26 Brown RF, Drawbaugh RB, Marrs TC: An investigation of possible models for the production of progressive pulmonary fibrosis in the rat. The effects of repeated intratracheal instillation of bleomycin. Toxicology 1988; 51:101-110.

27 Gabazza EC, Kasper M, Ohta K, Keane M, D’Alessandro-Gabazza C, Fujimoto $\mathrm{H}, \mathrm{Ni}$ shii Y, Nakahara H, Takagi T, Menon AG, Adachi Y, Suzuki K, Taguchi O: Decreased expression of aquaporin-5 in bleomycin-induced lung fibrosis in the mouse. Pathol Int 2004;54:774-780.

28 Schmidt R, Ruppert C, Markart P, Lubke N, Ermert L, Weissmann N, Breithecker A, Ermert M, Seeger W, Gunther A: Changes in pulmonary surfactant function and composition in bleomycin-induced pneumonitis and fibrosis. Toxicol Appl Pharmacol 2004; 195:218-231

-29 Gong LK, Li XH, Wang H, Zhang L, Cai Y, Qi XM, Liu LL, Liu YZ, Wu XF, Chen FP, Huang CG, Ren J: Feitai attenuates bleomycin-induced pulmonary fibrosis in rats. Biol Pharm Bull 2004;27:634-640.

-30 Serrano-Mollar A, Closa D, Prats N, Blesa S, Martinez-Losa M, Cortijo J, Estrela JM, Morcillo EJ, Bulbena O: In vivo antioxidant treatment protects against bleomycin-induced lung damage in rats. Br J Pharmacol 2003;138:1037-1048.

31 Horiuchi H, Uejima Y, Sakuma Y, Kadota T, Okada N, Taniguchi K, Takenouchi K, Yamanaka Y, Uno H, Komoriya K: Beneficial effects of a novel anti-hypoxemic agent, tei7322 , on bleomycin-induced experimental hypoxemia in rats. Eur J Pharmacol 1995; 287:27-34
32 Corbel M, Caulet-Maugendre S, Germain N, Molet S, Lagente V, Boichot E: Inhibition of bleomycin-induced pulmonary fibrosis in mice by the matrix metalloproteinase inhibitor batimastat. J Pathol 2001;193:538-545.

-33 Oury TD, Thakker K, Menache M, Chang LY, Crapo JD, Day BJ: Attenuation of bleomycin-induced pulmonary fibrosis by a catalytic antioxidant metalloporphyrin. Am J Respir Cell Mol Biol 2001;25:164-169.

34 El-Medany A, Hagar HH, Moursi M, At Muhammed R, El-Rakhawy FI, El-Medany G: Attenuation of bleomycin-induced lung fibrosis in rats by mesna. Eur J Pharmacol 2005;509:61-70.

-35 Chen F, Gong L, Zhang L, Wang H, Qi X, Wu X, Xiao Y, Cai Y, Liu L, Li X, Ren J: Short courses of low dose dexamethasone delay bleomycin-induced lung fibrosis in rats. Eur J Pharmacol 2006;536:287-295.

36 Katsuma S, Nishi K, Tanigawara K, Ikawa H, Shiojima S, Takagaki K, Kaminishi Y, Suzuki Y, Hirasawa A, Ohgi T, Yano J, Murakami Y, Tsujimoto G: Molecular monitoring of bleomycin-induced pulmonary fibrosis by cDNA microarray-based gene expression profiling. Biochem Biophys Res Commun 2001;288: 747-751.

37 Levitzky MG: Pulmonary Physiology, ed 4. New York, McGraw-Hill, 1995.

38 Mansoor JK, Hyde DM, Schelegle ES: Contribution of vagal afferents to breathing pattern in rats with lung fibrosis. Respir Physiol 1997; 108:45-61.

-39 Schelegle ES, Walby WF, Mansoor JK, Chen AT: Lung vagal afferent activity in rats with bleomycin-induced lung fibrosis. Respir Physiol 2001;126:9-27.

40 Dolhnikoff M, Mauad T, Ludwig MS: Extracellular matrix and oscillatory mechanics of rat lung parenchyma in bleomycin-induced fibrosis. Am J Respir Crit Care Med 1999; 160:1750-1757.

41 Riley DJ, Kerr JS, Berg RA, Ianni B, Edelman NH, Prockop DJ: Effect of cis-4-hydroxy-1proline on lung mechanics and collagen content of bleomycin-treated hamsters. Chest 1981;80:49-50.

42 Horiuchi T, Ikegami M, Cherniack RM, Mason RJ: Increased surface tension of the lung and surfactant in bleomycin-induced pulmonary fibrosis in rats. Am J Respir Crit Care Med 1996;154:1002-1005.

43 Srivastava M, Steinwede K, Kiviranta R, Morko J, Hoymann HG, Langer F, Buhling F, Welte T, Maus UA: Overexpression of cathepsin $\mathrm{K}$ in mice decreases collagen deposition and lung resistance in response to bleomycin-induced pulmonary fibrosis. Respir Res 2008;9:54.

44 Card JW, Voltz JW, Carey MA, Bradbury JA, Degraff LM, Lih FB, Bonner JC, Morgan DL, Flake GP, Zeldin DC: Cyclooxygenase-2 deficiency exacerbates bleomycin-induced lung dysfunction but not fibrosis. Am J Respir Cell Mol Biol 2007;37:300-308. 
-45 Casey J, Kaplan J, Atochina-Vasserman EN, Gow AJ, Kadire H, Tomer Y, Fisher JH, Hawgood S, Savani RC, Beers MF: Alveolar surfactant protein d content modulates bleomycin-induced lung injury. Am J Respir Crit Care Med 2005; 172:869-877.

46 Cavanaugh D, Travis EL, Price RE, Gladish G, White RA, Wang M, Cody DD: Quantification of bleomycin-induced murine lung damage in vivo with micro-computed tomography. Acad Radiol 2006;13:1505-1512.

-47 Gunther A, Lubke N, Ermert M, Schermuly RT, Weissmann N, Breithecker A, Markart P, Ruppert C, Quanz K, Ermert L, Grimminger F, Seeger W: Prevention of bleomycin-induced lung fibrosis by aerosolization of heparin or urokinase in rabbits. Am J Respir Crit Care Med 2003;168:1358-1365.

48 Lynch DA, Hirose N, Cherniack RM, Doherty DE: Bleomycin-induced lung disease in an animal model: correlation between computed tomography-determined abnormalities and lung function. Acad Radiol 1997;4:102107.

-49 Newman RA, Siddik ZH, Travis EL, Followill D, Ayele W, Burditt T, Krakoff IH: Assessment of pulmonary and hematologic toxicities of liblomycin, a novel bleomycin analog. Invest New Drugs 1990;8:33-41.

50 Voltz JW, Card JW, Carey MA, Degraff LM, Ferguson CD, Flake GP, Bonner JC, Korach KS, Zeldin DC: Male sex hormones exacerbate lung function impairment after bleomycin-induced pulmonary fibrosis. Am J Respir Cell Mol Biol 2008;39:45-52.
51 Mitzner W, Tankersley C: Interpreting $\mathrm{P}_{\mathrm{enh}}$ in mice. J Appl Physiol 2003;94:828-831; author reply 831-822.

52 Bates J, Irvin C, Brusasco V, Drazen J, Fredberg J, Loring S, Eidelman D, Ludwig M, Macklem P, Martin J, Milic-Emili J, Hantos Z, Hyatt R, Lai-Fook S, Leff A, Solway J, Lutchen K, Suki B, Mitzner W, Pare P, Pride $\mathrm{N}$, Sly $\mathrm{P}$ : The use and misuse of $\mathrm{P}_{\text {enh }}$ in animal models of lung disease. Am J Respir Cell Mol Biol 2004;31:373-374.

53 Lomask M: Further exploration of the penh parameter. Exp Toxicol Pathol 2006;57 Suppl 2:13-20.

54 Petak F, Habre W, Donati YR, Hantos Z, Barazzone-Argiroffo C: Hyperoxia-induced changes in mouse lung mechanics: forced oscillations vs barometric plethysmography. J Appl Physiol 2001;90:2221-2230.

55 Adler A, Cieslewicz G, Irvin CG: Unrestrained plethysmography is an unreliable measure of airway responsiveness in BALB/C and c57bl/6 mice. J Appl Physiol 2004;97: 286-292.

56 Arai T, Abe K, Matsuoka H, Yoshida M, Mori M, Goya S, Kida H, Nishino K, Osaki T, Tachibana I, Kaneda Y, Hayashi S: Introduction of the interleukin-10 gene into mice inhibited bleomycin-induced lung injury in vivo. Am J Physiol Lung Cell Mol Physiol 2000;278:L914-L922.
57 Ortiz LA, Gambelli F, McBride C, Gaupp D, Baddoo M, Kaminski N, Phinney DG: Mesenchymal stem cell engraftment in lung is enhanced in response to bleomycin exposure and ameliorates its fibrotic effects. Proc Natl Acad Sci USA 2003;100:8407-8411.

58 Genovese T, Di Paola R, Mazzon E, Muia C, Caputi AP, Cuzzocrea S: Melatonin limits lung injury in bleomycin-treated mice. J Pineal Res 2005;39:105-112.

-59 Yildirim Z, Kotuk M, Iraz M, Kuku I, Ulu R, Armutcu F, Ozen S: Attenuation of bleomycin-induced lung fibrosis by oral sulfhydryl containing antioxidants in rats: Erdosteine and N-acetylcysteine. Pulm Pharmacol Ther 2005;18:367-373.

-60 Nakagome K, Dohi M, Okunishi K, Tanaka $\mathrm{R}$, Miyazaki J, Yamamoto K: In vivo IL-10 gene delivery attenuates bleomycin induced pulmonary fibrosis by inhibiting the production and activation of TGF- $\beta$ in the lung. Thorax 2006;61:886-894.

61 Yildirim Z, Kotuk M, Erdogan H, Iraz M, Yagmurca M, Kuku I, Fadillioglu E: Preventive effect of melatonin on bleomycin-induced lung fibrosis in rats. J Pineal Res 2006; 40:27-33.

62 Liebler JM, Lutzko C, Banfalvi A, Senadheera D, Aghamohammadi N, Crandall ED, Borok Z: Retention of human bone marrowderived cells in murine lungs following bleomycin-induced lung injury. Am J Physiol Lung Cell Mol Physiol 2008;295:L285-L292. 